\title{
What makes critical research in political economy?
}

\section{Bill Dunn}

Nobody thinks of themselves as uncritical. So there is no neat definition of what constitutes critical political economy. The field is unbounded and fecund.

There are diverse schools of critical political economy - classical, Marxist, institutional, Keynesian, feminist, ecological, to name just a few - with each having many strands. Some research draws on several traditions or refuses categorisation. And while it will be suggested below that a useful understanding of what constitutes critical political economy can be approached through the negative, through opposition to the economic mainstream, some critics raid behind enemy lines to acknowledge and engage with insights from orthodoxy. Many researchers draw on different academic disciplines: on history, sociology, anthropology and political science. Research areas range across issues and across time. Some studies explicitly focus on the global economy, others on specific local contexts, with important work done at all sorts of scales in between. Therefore, critical political economists differ from their mainstream counterparts not only in terms of method, but at least as much in terms of the questions they ask, the nature and breadth of the research agenda. Neither the themes discussed in this introduction nor the chapters in this book can possibly be comprehensive.

But to begin with the negative, critical political economists believe that economics in the form that dominates university departments, at least across the Anglophone world, is profoundly flawed and profoundly conservative. At best it provides an insufficient basis for understanding complex economic realities. At worst it amounts to a crude and fanciful apology for the existing economic system. It is therefore useful to begin by offering some broad outlines of a critical research agenda in contrast to the approaches of this orthodoxy. There are now many useful books which provide much more thorough overviews and critiques of conventional economic thinking (e.g. Green and Nore 1977; Heilbroner and Milberg 1995; Lawson 1997; Milonakis and Fine 2009), and 
I am delighted that contributors to this volume have resisted the considerable temptation to spend large amounts of their space venting frustration with the assumptions and practices of orthodoxy. The purpose here is to move towards a positive articulation of research agenda. But a few themes seem particularly relevant to understanding and developing such an alternative, critical, approach.

Perhaps most fundamentally, economics or political economy should be a social science. People do not behave like inanimate objects. A few things follow. First, a radical individualism makes no sense and important and interesting questions develop precisely out of thinking about the relations between individuals, institutions and social structures. Second, the methods of a natural science like physics at best provide one weapon in a critical political economist's arsenal. The economy cannot simply be studied in the same way as physical processes. Third, time and space are experienced unevenly. There is often a path dependence to economic action, not an oscillation around equilibrium. The spaces and places, the interaction over distances, the heterogeneous material world in which we live, all shape economic activity profoundly. Not only are we learning how economic activity is transforming the environment, but we are also learning how the environment shapes the economy. Fourth, and finally, political economy is not a 'neutral' academic endeavour, divorced from the object it studies. How we see the world, and what we say about the world, is inseparable from our position within it. Potentially, what we say about the world also has consequences, and can possibly be used to change that world. As Robert Cox writes, 'Theory is always for someone and for some purpose' (1981: 128). We need to ask 'who gains' from particular theories and policies.

To repeat, there is no clear dividing line between the critical and uncritical. There is however a risk of caricature. Binary depictions of us and them, of good and bad or even of fundamentally opposed 'modes' of economics (Tabb 1999) at best oversimplify. Particularly since the global financial crisis of 2008, some prominent figures have acknowledged the shortcomings of their discipline. Some famous economists can be claimed by both the mainstream and the critics. Keynes is probably the clearest example. I will quote him approvingly below, but it would be possible to find formulations where he appears to sit on the other side of the fence, or at least where he sits on the fence, as was his wont. Some of Keynes's followers, including contributors to this volume (usually seen as 'post-Keynesians'), can be radical critics of both mainstream economics and the existing economic order. Other followers have been safely absorbed back into the mainstream. Some still hover in the centre ground, claiming both a political centre and insisting that their economics is simultaneously radical and capable of satisfying the standards of orthodoxy (Davidson 
1978, 2007). But I think most people would recognise the broad distinctions between orthodoxy and critical political economy, and I hope the themes that follow can help to inform the development of a critical research agenda, which is exemplified in the chapters in this book that are briefly introduced below.

\section{Economics as a social science}

It is useful to begin by saying that critical political economists see what they do as a social science. This has several dimensions. But political economy as it was originally conceived and taught in the 18th and 19th centuries was understood to be what was then called a 'moral science'. The radical separation of economics from broader historical and social concerns and the insistence that economics had distinct and proper methods were 20th-century innovations, which had some seriously deleterious consequences.

Standard definitions of economics as 'the study of scarcity, the study of how people use resources and respond to incentives, or the study of decision-making' (American Economic Association 2020) rule out most of what actually makes the economic world go round and which critical political economists want to put (back) in. Political economy should ask the questions which preoccupied the classical tradition of Adam Smith and David Ricardo about work and about how resources are produced in the first place; should ask the Marxist questions of exploitation and class; the questions of the Institutionalist and German historical schools about formal and informal institutions, not least about the nature and role of the state. It should ask about time and how the past informs the present; should ask the Keynesian questions about decisions made in conditions of uncertainty, the relation between money and the 'real' economy, and about the relations between production and demand; should ask the feminist questions about how the political economy is gendered both in fact and in the way it is conceived to prioritise some issues and undervalue others like domestic labour; should ask questions about space and land, nature and place, and the relationship between economy and ecology. Critical political economy asks much else besides. Even if no one researcher can do all this at once, a recurring theme for critical political economists is interconnectedness; of different aspects of the economy with each other and of the economy with the rest of society.

There is therefore usually a recognition of the need to engage with, and to learn from, other social scientists. At the same time this creates difficult questions about where to stop. It is impossible to know everything and the objection that 
'it is more complicated than that', while never wrong, is seldom helpful. It also creates difficult questions about analytical priorities, which the postmodern moment has made people shy of declaring. But it is impossible not to prioritise in practice and far better that these priorities are made explicit and subject to criticism than driven underground. Along with a commitment to a broader approach, come responsibilities to make clear exactly what is being studied and how.

Because there are many different traditions of critical political economy, there are also often sharp disagreements. Indeed, the diversity of interpretations is one of the characteristics of the critical, a consequence of rejecting the existence of established authority on what constitutes 'proper' economics. But while this means that it is possible to find critical political economists saying mutually incompatible things, it also means that, as in other social sciences, there is broad agreement that disagreement should be allowed, even encouraged. This would be too obvious to need saying among sociologists or political scientists. It contrasts sharply with mainstream economics, where the bounds of appropriate disagreement are very narrow. The established right way of doing things, in Stephen Rousseas's phrase, allows its adherents, to 'engage themselves in the endless task of paradigm polishing' (1986: 16). For the critics, there are fewer established principles but more exciting, neglected avenues of legitimate enquiry and different ways of getting critical purchase on important issues.

Some implications of insisting that economics should a social science, not an 'objective', natural, science, seem worth developing a bit further.

\section{Structure and agency}

If interdependence is a recurring theme for critical political economists, a particularly crucial interdependence is that between human agency and social structures. We make our own world as it makes us (Onuf 1997; Marx 2010).

This contrasts sharply with most mainstream economists, who - with honourable exceptions (e.g. Arrow 1994), and if they bother to think about such philosophical questions at all - generally subscribe to methodological individualism. Crudely, to paraphrase Margaret Thatcher's famous formulation, 'there is no such thing as society, there are only individuals'. Attempting to reduce people to something akin to (19th-century) physics' atomic level, we must all be reckoned simple, selfish, rational, utility maximisers. To quote 
William Stanley Jevons, one of the founders of modern marginalism, 'each person is to other persons a portion of the outward world ... Hence the weighing of motives must always be confined to the bosom of the individual' (1957: 14). Any apparent 'society' is then simply the sum of those individual parts. In principle, for the mainstream, the (unfortunate) reality of institutions can be explained away by aggregating individual utilities to give us firms (Coase 1937; Williamson 1975) or states (Tullock 1987). The insistence on methodological individualism can then also become the basis for 'economics imperialism' (Fine and Milonakis 2009), which exports the methods of a de-socialised economics to other social sciences. There are more sophisticated defences of individualism and important questions whether this is really a methodological or ontological issue (Hayek 1948). But even more subtle versions either end up with a rather banal circularity or smuggling presuppositions of the social back into their understanding of individuals (Lukes 1973).

Accordingly, most critical political economists acknowledge an inseparable relation between structure and agency, albeit they see this in different ways and put more or less stress on structure or agency. Often, they are concerned precisely with the relation between the two (Lawson 1997). Each individual is born into an already existing society and, as Keynes insists, 'the whole is not equal to the sum of the parts, comparisons of quality fail us, small changes produce large effects' (2013: 262). Keynes continues that economics should be a 'moral science':

I mentioned before that it deals with introspection and with values. I might have added that it deals with motives, expectations, psychological uncertainties. One has to be constantly on guard against treating the material as constant and homogeneous. It is as though the fall of the apple to the ground depended on the apple's motives, on whether it is worth while falling to the ground, and whether the ground wanted the apple to fall, and on mistaken calculations on the part of the apple as to how far it was from the centre of the earth. (2012: 300)

Modern behavioural economists, more likely than most to secure a foothold in mainstream departments, have highlighted how even put in 'laboratory conditions' people seldom behave as the rational utility maximisers mainstream economics supposes. Among other things, people behave differently towards others depending on those others' social location and they value gain and loss very differently (Hargreaves Heap, Chapter 8 in this volume; Kahneman 2012).

Several advocates of methodological individualism build their arguments on a false claim that the only possible alternative is a structuralist-functionalism. Some political economies have slipped into something close to this, but, of course, opposition to radical individualism need not say that individuals do 
not matter. It is merely necessary to say and to investigate how our thoughts and actions are themselves social, always developed in relation to other people. This leaves open important questions of how best to research relations between structure, and the many different social structures, and agency, to which critical political economists respond in different ways.

Marxists, in particular, usually begin with the structures, particularly emphasising 'big picture' issues of class, even as these are understood to be dynamic and changing and mutable, with key research questions around how social struggles transform economic relations. Challenges, from both within and without the Marxist tradition, research how class relates to other structures, notably those of race and gender (Hartmann 1981; Walby 1986; Collins 2000; Matthaei 1996). Feminist economists have identified both the implicit assumptions in conceiving economics in terms of rational economic 'man' (Hewitson 1994) and the empirical limits of conventional categories, including conceptions of 'the household' as a suitable standard unit of analysis. At the very least, for critical political economists, questions of inequality (Stilwell, Chapter 2 in this volume) loom large, and if as political economists the economic is a core concern, this is multidimensional and inherently inseparable from other processes. The importance of institutions, of formal institutions but also of ideological 'regimes', has become central to many recent research agenda. Other critical political economists are more likely to begin with agency and social movements and investigate how social pressures are experienced and resisted.

\section{Beyond physics envy and an obsession with mathematical formalism}

A second way of thinking about the differences of method between critical and mainstream economics can then be couched in terms of the accusation that the mainstream suffers from 'physics envy' (Mirowski 1992). Economists themselves would be more likely to couch this in terms of 'rigour', and critical political economists, of course, are perfectly capable of writing woolly nonsense the mainstream seeks to avoid. But there are important differences in what constitutes acceptable method and profound problems with claims that economics should look more like natural science than social science.

Any such 'physics envy' is probably most conspicuous in the mainstream's penchant for complex mathematics. To quote Jevons again, '[m]y theory of Economics is entirely mathematical in character ... I do not hesitate to say, too, that Economics might be gradually erected into an exact science, if only com- 
mercial statistics were far more complete and accurate than they are at present' (1957: 14, 21). Jevons notwithstanding, for many years it remained acceptable to write in straightforward prose. Alfred Marshall, effective leader of the next generation of mainstream economists in Britain around the beginning of the 20th century and largely responsible for separating economics teaching from the 'moral sciences' at Cambridge, nevertheless famously recommended translating any mathematics into plain English, and if that proved impossible, recommended deleting the mathematics. In the US, at least until the middle of the 20th century, economics graduate students were required to read German in order to access the work of the non-mathematical German historical school (Fusfeld 2002). Most academic economics articles up to the mid-century would still have been comprehensible by non-specialists, a deficiency now radically corrected. In its turn to mathematics and in the furnishing of statistics, 150 years since he wrote these words, economics has fulfilled Jevons's ambitions more fully than he could have imagined.

Critical political economists tend to be less fond of mathematical formalism. In a sense this is just intellectual honesty. A leading mainstream economist can acknowledge that what they do is not really science but a mixture of 'fiction and journalism' (Leamer 2012). Of course, many mainstream mathematical economists who occupy prestigious positions do invaluable work. There is something particularly satisfying when statistics coming out of the International Monetary Fund (IMF) show that inequality is also bad for growth or research coming out of the World Bank acknowledges that microfinance initiatives they have promoted are counter-productive. But a wariness of abstract mathematical arguments flows from critical political economists' views of the world and their relation to it, the inherent difficulty reducing to algebra what are complex relations between individuals and social structures, concerns with history and time and space, and questions of politics and power.

This does not require an out-of-hand rejection of mathematics, let alone of precise reasoning, and critical political economists take different attitudes. Almost all would agree that the mainstream overdoes it; that it habitually assumes a specious precision unreflective of the complexities of the social world it purports to describe. At best, mathematical equations are tautologies. As such they can be useful, helping to identify which factors are reckoned to be related and how, and to suggest ways of testing those relations empirically. But they can also lend themselves to a misleading view that economic variables should be understood as effectively independent of one another (like the ground and the apple). At least some of the routine mainstream practices are manifestly flawed. 
A phrase in an old introduction to calculus, a mathematics not an economics book, recently caught my attention. Having used some monetary illustrations, the author quickly adds 'but money is not a good example for the calculus, because it generally comes and goes by jumps, not by a continuous flow' (Thompson 2012: 54). A great deal of modern economics, not least Friedman's (1987) version of the quantity theory of money, seems blithely unaware that the methods so useful to physicists may be completely inappropriate.

Most critical political economists would share Keynes's wariness of formal mathematical presentation in preference for 'ordinary discourse' where 'we can keep "at the back of our heads" the necessary reserves and qualifications' (1973: 297). Some critical political economists would go further in their hostility to the mainstream use of maths, insisting on more qualitative and agent-centred approaches. But without needing to be anti-mathematical there is a predisposition to methodological pluralism. As social scientists in many other disciplines would recognise (as indeed would many natural scientists), there is no single right way of doing things. There are different paths to analytical rigour and to deep understanding.

\section{The complexity of time and space}

Among other things, questions of time and space can make social life recalcitrant to mathematical formalism. Largely overlooked by the mainstream, the irreversible nature of time is crucial to much of critical political economy (Robinson 1964). History matters and impinges on current practices. In Marx's phrase, 'the tradition of all the dead generations weighs like a nightmare on the brain of the living' (2010: 103). Research in critical political economy is often concerned with history, with how capitalism came into being, with its changing forms but also how established institutions shape current practice.

One particularly influential contribution to understanding both history and the present is the idea of 'circular and cumulative causation'. Rather than any deviation from the norm being quickly and automatically corrected by market pressures towards equilibrium, there is often a path dependency as small changes beget bigger ones. Myrdal's (1944) original example described a vicious circle of poverty among, and racism towards, black Americans. But the idea has been extended to other areas, from technological innovation to spatial agglomeration and uneven development. Rather than a static equilibrium, questions of rupture and crisis and changes of direction become particularly fascinating. 
Many critical political economists go further to endorse notions of uncertainty in Keynes's sense that at least some future events are radically unknowable. Despite which, we are required to act, not only knowing that the future is unknowable but also knowing that other people, on whose actions we depend, similarly lack any secure basis for knowing the consequences of their actions. Some post-Keynesians accept that such an understanding of uncertainty can spin out into what Alan Coddington labelled 'analytical nihilism' (Coddington 1983; Shackle 1972). At the other end of the spectrum, Marxists are more likely to see capitalism both as the driver of uncertainty and volatility and as providing imperatives which are difficult to escape. For Anwar Shaikh there are 'ordered patterns' but these 'are neither steely rails nor mere constellations of circumstance. They are, rather, moving limits whose gradients define what is easy and what is difficult at any moment of time' (2016: 5). At the very least, as Davidson (1978) insists, the future is not the statistical shadow of the past. The mainstream fondness for extrapolation and economic forecasting is often fundamentally misguided, taking away the possibility of 'choice' on which it claims to be predicated.

Perhaps particularly in recent years, critical political economists have also become profoundly interested in questions of space and territory. In fairness, economists within or very close to the mainstream have also recognised the importance of spatial relations and the previously inadequate treatment of this (Krugman 1979, 1993). But critical political economists have been particularly responsive to ecological concerns and the relationship between people and the (rest of) nature and the interaction of economic processes at different scales.

Problems of 'scale' are addressed explicitly in what follows by our geographers Eric Sheppard and Andy Herod. They are also raised among others by Frank Stilwell's discussion of inequality, Sheila Dow's discussion of finance and Alessandra Mezzardi's discussion of field economics. Among other things, we have inequalities between countries but also within them, including spatial differences, which are often less well measured by conventional national accounting techniques. Stimulated in part by claims of 'globalisation' and the inadequacy of both the liberalising-globalising literature and nation-state-based alternatives, critical thinking has challenged the individual-state binary, vulnerable not least to transposing the individualist methods of the mainstream onto state structures as if they too had subjective utilities. The national bases of data collection still present formidable challenges, and potential areas of constructive research, but there is a growing awareness of the interaction of processes and actions over different scales, within countries and regions as well as simply at individual, national and global levels. 


\section{A socially concerned social science}

Finally, but to return to the idea of what we do as a moral science, most critical political economists ask questions about 'for whom?'. Who gains from particular economic practices? Who gains from particular economic ideas? There are seldom universal interests in one path rather than another and economic theories which purport to identify straightforwardly better or worse ways of acting are usually misleading.

This can also be true of natural science. Rather than an objective pursuit of truth, the scientific research which is actually carried out may be that which is sponsored by the arms industry. Medical research is sponsored by pharmaceutical companies, aware that diseases of poverty are less likely to be lucrative than those of the rich. But it is probably particularly straightforward in economics. Financial models get built into the computer programs, which predict stability and are used to value assets in ways that then provoke instability. Mainstream economic theorising gets built into policies, like those of 'Inflation Targeting', which prioritise 'sound' money and the interests of wealthy asset holders over employment or welfare spending.

Most critical political economists would therefore agree that research is never neutral. But questions of what is to be done, perhaps the most vital dimension raised by Cox's aphorism that theory is always for somebody and for some purpose, bring out some vivid differences. There is little consensus on questions of for whom or to what end do we research or of strategies for change.

Economists of the Austrian School (followers of the likes of Ludwig von Mises and Friedrich Hayek) would share many of the criticisms of mainstream, marginalist, equilibrium approaches raised above. But they can draw right-wing libertarian or even fascist conclusions. While the Austrians are not represented in what follows, and most critical political economists, like most social scientists, would today position themselves somewhere from the political centre leftwards, that leaves a very wide space and scope for very different priorities. Most critical political economists favour more egalitarian outcomes. Some write explicitly in class terms. Others prioritise gender inequalities and redressing them. An emphasis on the Global South and its disadvantage or exploitation and in overcoming this is the focus for many writers. These goals may be complementary, but there can also be tensions between them, which tensions themselves provide the basis for important research projects. 
In terms of strategy, too, critical political economists, including contributors to this volume, answer in different ways. Some envisage better policies for national economies. Many writers share Keynes's vision of national interests and of an essentially benign state, or at least of a state capable of reform and potentially receptive to better advice. Jonathon Goldstein and Michael Hilliard go so far as to see heterodox economists as required to 'provide sound policy recommendations' (2009: 4). Other critical political economists, without necessarily rejecting the potential for policy reform, are more likely to point to the failures of the state and to emphasise non-state, social movement activism (Gibson-Graham 1996; Matthaei, Chapter 15 in this volume). The Marxist tradition, of course, while not necessarily opposed to either reform strategy, sees them as inherently limited without more radical, revolutionary change. But most critical political economists at least try to keep in the back of their minds that what they write is not a neutral scientific endeavour and to think about the implications for economic and political practice.

For the most part, economic thinking today is dominated by an individualised and abstractly mathematical mainstream which purports to maintain a disinterested scientific objectivity. Against this, other critical political economists would construct different lists of alternative principles from those above. The critics are a relatively small but diverse minority. A few manage to sustain departments where critical economic thinking is encouraged. Some survive and work within otherwise mainstream economics departments, others find shelter in other disciplines. These institutional settings shape what research is possible, but in different ways there is an attempt to create a more socially aware and more socially responsible economic research agenda.

\section{Some avenues for enquiry, some done and undone research}

The following chapters provide a flavour of critical research in political economy, sketching a research agenda in different ways. Some set out the 'state of the art', some identify problems and domains of done and undone research and questions worth pursuing, some draw on specific examples of their own research to illustrate how further work might be done. Several address the normative dimensions and suggest what might be done better not only in research but in practice. The chapters are short and broadly speak for themselves, so here the content of each can be introduced briefly. 
Frank Stilwell's chapter on inequality (Chapter 2) is concerned with both causes and consequences. In both cases the chapter argues for the need for clarity in developing concepts and theories. There are linked but distinct inequalities of wealth and of income. Stilwell invokes Myrdal's (1944) 'circular and cumulative causation' to argue how rather than being pulled back to an equilibrium, inequalities of wealth tend to build inequalities of income, reinforcing inequalities of wealth. He sees a need for broad political economy research concerned with social structures and processes to be linked with 'more micro-scale research undertaken by sociologists and anthropologists'. Stilwell is also concerned with strategies and policies for a more equal society. His emphasis is on how public policy and the state can make a difference, but he also sees a role for the labour movement and non-governmental organisations (NGOs). Stilwell also raises questions of scale, of inequality within and between countries, an important theme developed in several of the following chapters.

Benjamin Selwyn's chapter (Chapter 3) argues that something as apparently simple as 'growth', so commonly assumed to be a universal good, needs to be critically interrogated. In particular, the acceptance of growth as a goal obscures the social class relations on which it is predicated. Growth is achieved by exploiting labour, and (as is now being more widely acknowledged) the way it has hitherto been achieved ultimately undermines ecological sustainability. Selwyn uses Marx to examine questions of development and poverty and how two distinct but related processes, of dispossession and of labour exploitation, produce new forms of poverty. He points to a vicious cycle where growth is seen as the means to overcome poverty and inequality but the means by which growth is achieved themselves generate poverty and inequality. Selwyn emphasises the problems of conceiving alternatives to mainstream individualism in national and nation-state-based terms and considers alternatives to growth-based development. At least, we should deprioritise and contextualise growth in our research agenda.

Sheila Dow (Chapter 4) develops a critical research agenda on money, finance and the state. She discusses the importance of financial institutions and institutional change, pointing out that 'the subject matter does not stand still'. The emergence of cryptocurrencies is a telling case in point. Reflecting on the implications of the 2008 global financial crisis, Dow considers the role of policy and central banks in promoting financial but also social stability. ' $[\mathrm{M}]$ oney's nature is social', so there is an interconnectedness of state and private institutions, of monetary and financial policy, and of these with the broader economy. Dow's approach contrasts not only with the mainstream but with some other heterodox writers who insist on a rigid exogenous/endogenous or state/market 
distinction. As Dow (1996) herself argued previously, for the critical political economist nothing bar 'acts of god' is truly exogenous and part of the research task is to understand, not exclude, the state. Here she considers the role of state monopolies of money, including proposals for central bank digital currencies, and the role of regulation. She argues that, given systemic financial instability, as identified by Minsky, 'it is up to the state to intervene to moderate it'. Policy, Dow argues, also needs to address environmental concerns, and while most of the research (including heterodox research) on money and finance has taken the Western system as its model, the situation may be very different in developing countries.

Nour Dados says much more on this in her chapter on Southern theory (Chapter 5). She looks at how the Global South has been central to capitalism's history while indigenous economies and knowledges have been disrupted and destroyed. The chapter describes an uneven creation and circulation of knowledge, embedded in a global division of intellectual labour, itself built upon the violence of colonialism, imperialism and economic domination. But Dados also describes attempts to recuperate subaltern epistemologies and how these can inform contemporary research agenda, arguing that the contributions of post-colonial intellectuals and Global South perspectives are vital to understanding global capitalism and knowledge creation in the neo-colonial, neoliberal world.

Bill Dunn (Chapter 6), sketching a potential critical research agenda on international trade, is probably more sympathetic than most to a constructive, critical engagement with mainstream trade theory, but argues that it needs to be put in its place; that it is also necessary to examine how international trade relations are constructed, both historically and in relation to other social and economic processes. Like Selwyn, he identifies the problems with national-based alternatives to liberalism, which share many of the same presumptions about national interest and 'growth' as if it were something straightforwardly desirable. He argues that a pervasive 'methodological nationalism' has been an obstacle to developing a genuinely critical research agenda on international trade, leaving un-investigated many important dimensions of trade's causes and consequences.

Alessandra Mezzadri's work on sweatshop economics (Chapter 7) epitomises the conceptual pay-off for 'fieldwork economics', looking beneath apparently equitable trade relations to investigate how those relations are constructed and what they mean for the workers involved. Where mainstream trade theory assumes that countries have 'factor endowments', Mezzadri asks how those factors, particularly labour, are produced and reproduced very differ- 
ently within countries, based on complex social differentiation and power relations, among other things according to gender and caste. She contests the individualism of conventional microeconomics and the broad sweeps and generalisations of macroeconomics. Her field-based research agenda draws on sociology, human geography and development studies and shows how the study of production, exchange and inequality must transcend rigid divisions between the global, the national and the local.

Shaun Hargreaves Heap's chapter (Chapter 8) addresses some similar themes of structure and agency while adopting an apparently radically different research strategy. Experimental economics puts volunteers in 'laboratory' situations to consider how they behave in different circumstances. Hargreaves Heap is able to show, in a controlled way, how the 'social, institutional or historical framing', how questions of social identity and context, affect what appear to be 'individual' decisions. His discussion of 'chat opportunities' shows that deliberative procedures are conducive to the public good, with implications for formal democracy but also, surely, for how resistance can be built. '[P] eople behave differently in the same situation depending on whether they are interacting with a fellow member of their group or with someone who belongs to another.' One implication that Hargreaves Heap draws from this is that in-group identity with the rich may make people less likely to support egalitarian reform, which would be in their interest. Hargreaves Heap's experimental results also show that people appear less likely to favour redistribution if they feel that inequality derives from individual decisions rather than luck, potentially shedding light on why health care is widely supported but also differences between European attitudes and those in the US, where income is more likely to be attributed to individual effort or skill. But as Hargreaves Heap concludes, 'there is a key question that needs addressing about how people come to hold views on the relative contribution of each in determining outcomes'. He ends with an elegant liberal argument for equality. If individual autonomy is the objective, it matters equally for all individuals and can only be achieved in an egalitarian society.

The following three chapters raise 'big picture' issues concerned with space and time. Andrew Herod (Chapter 9) explores how different conceptualisations of time, space and the geographical scale at which social life is organised have implications for understanding the geography of capitalism and hence for political economy. He examines how different conceptions of time and space, among philosophers, scientists and social scientists, have important implications for how we conduct research. He describes how 'the different ways in which scales are described can shape how we understand the world to be organised geographically and so what we consider politically possible'. 
Questions of time have been particularly crucial to critical thinking about money in the post-Keynesian tradition, and Fernando Ferrari Filho and Fábio Henrique Bittes Terra (Chapter 10) turn to Keynes's views on uncertainty and its implications for modern financial markets. They show how an understanding of uncertainty as more than a probabilistic risk contrasts with that of the mainstream and undermines claims of the efficient market theory. The chapter shows that, once 'speculation is essentially an "activity of forecasting the psychology of the market", in an entrepreneur economy, the organisation of the financial market, given uncertainty, faces a severe trade-off between liquidity and speculation. It then shows how for this approach there are necessary links between the financial market and the real economy. Ideas of money's 'neutrality' are unsustainable, and the implication is that a research agenda needs to incorporate analyses of money and the 'real'.

Eric Sheppard (Chapter 11) explores the implications for Marxist political economy of thinking geographically about capitalism. He argues that in the wild' capitalism is inherently geographical. Uneven geographical development is less the result of place-based geographical characteristics than it is of the asymmetric and uneven connectivities between places and across scales. Socio-spatial poverty and marginalisation continue to be reproduced in different ways and are exacerbated by cultural and biophysical processes that exceed attempts to commodify them.

Similar themes are developed more concretely in the next three chapters. Sabine O'Hara's chapter (Chapter 12) advocates developing more context-conscious measures of economic performance. The chapter develops themes raised by feminist and ecological economics and advocates strategies of localisation and 're-embedding' the economy, at the same time as stressing the need for national and global levels of action. O'Hara gives the important example that '[c]heap food produced in industrial-scale farms may not be cheap at all, but may come at the expense of ecosystems and human health that carries enormous social costs'. The growing virtual economy is seen as providing the basis for localising solutions and an important arena for further research.

Franklin Obeng-Odoom (Chapter 13) proposes a Georgist political economy for understanding and redressing problems of urban land in Africa. Henry George was a US political economist of the late 19th century who emphasised the importance of land and advocated land taxes. Obeng-Odoom suggests a Georgist approach provides the basis for a critique of a mainstream agenda based on privatisation and individual property rights, and a mainstream practice based on financialisation and increasing debt. Obeng-Odoom's Georgist political economy emphasises that research questions should not simply be 
about private versus public but about whose interests are being pursued. It is also necessary to ask about the nature of political intervention in the economy and about who pays, in class terms and inter-generational terms. Public guarantees of financial interests exacerbate problems of urban indebtedness. The chapter's evidence focuses on Accra, Ghana, but also touches on similar research done in South Africa and Uganda, suggesting a research agenda applicable to the urban economy more generally, particularly in the growing cities of the Global South.

Ali Bhagat and Susanne Soederberg (Chapter 14) focus on refugees in the European Union to examine the political economy of displacement governance. Using empirical examples of Berlin and Paris as host cities, they explore questions of race and class and of space and scale. The chapter asks who benefits and why to describe the so-called refugee crisis and the depiction of refugees as a 'trope' which masks underlying issues of shelter insecurity and which is underpinned by systematic racial exclusion.

Julie Matthaei's provocative final chapter (Chapter 15) argues for a reconstructed Marxist-feminist-anti-racist-ecological economics and for 'thinking beyond capitalism'. Matthaei maintains that we live in times of epic crises and transformation and that political economists need to be active participants in change, through both their teaching and their research. Such a political economy can inform a solidarity economy, involving liberatory practices and institutions already emerging within capitalism even in its US heartlands. Theory and practice, as so often for critical political economists, are inseparable.

Other critical political economists including contributors to this volume would reach different strategic conclusions, but Matthaei's reference to crises prompts an important final coda. I am completing this introduction in London, in March 2020, as the UK follows other countries into lockdown in response to the Covid-19 virus. My sympathies with those who are ill and solidarity with those who are battling the disease in different ways. It is too soon to be confident about the course of the pandemic or about its broader impact. Beyond the horrors of the rising death toll, already we have seen employers seize an opportunity to lay off workers and to impose worse working conditions. We have seen governments find resources they said were unavailable while still the most vulnerable seem to get least. We know that when resources were suddenly found in 2008 to rescue the banks, it was not the financiers who were expected to pay later. But the response to the virus has also shown glimpses of better alternatives, community responses to look after their vulnerable, collective refusals to work where profit was trumping health. We are in 
an extraordinary crisis, which can make worrying about the best ways of doing political economy look frivolous, but which also makes critical reflection on how the world works, and how we can make it a better world, more pressing than ever.

\section{References}

American Economic Association (2020) What is economics, available at https://www .aeaweb.org/resources/students/what-is-economics, accessed 18 March 2020.

Arrow, K.J. (1994) Methodological individualism and social knowledge, American Economic Review, 84(2): 1-9.

Coase, R.H. (1937) The theory of the firm, Economica, 4(16): 386-405.

Coddington, A. (1983) Keynesian Economics: The Search for First Principles, London: George Allen \& Unwin.

Collins, P.H. (2000) Gender, black feminism, and black political economy, Annals of the American Academy of Political and Social Science, 568: 41-53.

Cox, R.W. (1981) Social forces, states and world orders, Millennium: Journal of International Studies, 10(2): 126-155.

Davidson, P. (1978) Money and the Real World, 2nd ed., London: Macmillan.

Davidson, P. (2007) Interpreting Keynes for the 21st Century, Volume 4: The Collected Writings of Paul Davidson, Basingstoke: Palgrave Macmillan.

Dow, S.C. (1996) The Methodology of Macroeconomic Thought: A Conceptual Analysis of Schools of Thought in Economics, Cheltenham, UK and Brookfield, VT, USA: Edward Elgar Publishing.

Fine, B. and Milonakis, D. (2009) From Economics Imperialism to Freakonomics: The Shifting Boundaries between Economics and Other Social Sciences, Abingdon: Routledge.

Friedman, M. (1987) Quantity theory of money, in Eatwell, J., Milgate, M. and Newman, P. (eds) The New Palgrave Dictionary of Economics, Vol. 4, London: Macmillan, pp. 3-20.

Fusfeld, D.R. (2002) The Age of the Economist, Boston, MA: Addison-Wesley.

Gibson-Graham, J.K. (1996) The End of Capitalism (As We Knew It), Cambridge, MA: Blackwell.

Goldstein, J.P. and Hilliard, M.G. (2009) Introduction: a second-generation synthesis of heterodox macroeconomic principles, in Goldstein, J.P. and Hilliard, M.G. (eds) Heterodox Macroeconomics: Keynes, Marx and Globalization, London: Routledge, pp. 3-23.

Green, F. and Nore, P. (eds) (1977) Economics: An Anti-Text, London: Macmillan.

Hartmann, H. (1981) The unhappy marriage of Marxism and feminism: towards a more progressive union, in Sargent, L. (ed.) The Unhappy Marriage of Marxism and Feminism, London: Pluto Press, pp. 19-33.

Hayek, F.A. (1948) Individualism and Economic Order, Chicago: University of Chicago Press.

Heilbroner, R. and Milberg, W. (1995) The Crisis of Vision in Modern Economic Thought, Cambridge: Cambridge University Press. 
Hewitson, G. (1994) Deconstructing Robinson Crusoe: a feminist interrogation of 'rational economic man', Australian Feminist Studies, 9(20): 131-149.

Jevons, W.S. (1957) The Theory of Political Economy, 5th ed., New York: Sentry Press.

Kahneman, D. (2012) Thinking, Fast and Slow, Harmondsworth: Penguin.

Keynes, J.M. (1973) The General Theory of Employment, Interest and Money, London: Macmillan.

Keynes, J.M. (2012) The Collected Writings of John Maynard Keynes, Volume XIV: The General Theory and After: Part II. Defence and Development, Johnson, E. and Moggridge, D. (eds) Cambridge: Cambridge University Press.

Keynes, J.M. (2013) The Collected Writings of John Maynard Keynes, Volume XX: Activities 1929-1931: Rethinking Employment and Unemployment Policies, Moggridge, D. (ed.) Cambridge: Cambridge University Press.

Krugman, P.R. (1979) Increasing returns, monopolistic competition, and international trade, Journal of International Economics, 9: 469-479.

Krugman, P.R. (1993) Geography and Trade, Leuven: Leuven University Press.

Lawson, T. (1997) Economics and Reality, London: Routledge.

Leamer, E.E. (2012) The Craft of Economics: Lessons from the Heckscher-Ohlin Framework, Cambridge, MA: MIT Press.

Lukes, S. (1973) Individualism, Oxford: Basil Blackwell.

Marx, K. (2010) Marx and Engels Collected Works, Vol. 11, Lawrence \& Wishart, ebook.

Matthaei, J. (1996) Why feminist, Marxist and anti-racist economists should be feminist-Marxist-anti-racist economists, Journal of Feminist Economics, 2(1): 22-42.

Milonakis, D. and Fine, B. (2009) From Political Economy to Economics: Method, the Social and the Historical in the Evolution of Economic Theory, Abingdon: Routledge.

Mirowski, P. (1992) Do economists suffer from physics envy? Finnish Economics Papers, 5(1): 61-68.

Myrdal, G. (1944) An American Dilemma: The Negro Problem and Modern Democracy, 7th ed., New York: Harper \& Brothers.

Onuf, N. (1997) A constructivist manifesto, in Burch, K. and Denemark, R.A. (eds) Constituting International Political Economy, Boulder, CO: Lynne Rienner, pp. 7-17.

Robinson, J. (1964) Economic Philosophy, Harmondsworth: Pelican

Rousseas, S. (1986) Post Keynesian Monetary Economics, Basingstoke: Macmillan.

Shackle, G.L.S. (1972) Epistemics and Economics: A Critique of Economic Doctrines, Cambridge: Cambridge University Press.

Shaikh, A. (2016) Capitalism: Competition, Conflict, Crises, Oxford: Oxford University Press.

Tabb, W.K. (1999) Reconstructing Political Economy, London: Routledge.

Thompson, S. (2012) Calculus Made Easy, London: Palgrave Macmillan.

Tullock, G. (1987) Public choice, in Eatwell, J., Milgate, M. and Newman, P. (eds) The New Palgrave: A Dictionary of Economics, London: Macmillan, pp. 1040-1044.

Walby, S. (1986) Patriarchy at Work, Cambridge: Polity Press.

Williamson, O. E. (1975) Markets and Hierarchies, New York: Free Press. 